\title{
Deep-sea meiofaunal and foraminiferal communities along a gradient of primary productivity in the eastern Mediterranean Sea
}

\author{
NIKOLAOS LAMPADARIOU ${ }^{1}$, ANASTASIOS TSELEPIDES ${ }^{2}$ and \\ ELENI HATZIYANNI ${ }^{1}$ \\ ${ }^{1}$ Hellenic Centre for Marine Research, Inst. of Oceanogr., PO Box 2214, 71003, Heraklion, Crete, Greece. \\ E-mail: nlamp@her.hcmr.gr \\ ${ }^{2}$ Univ. of Piraeus, Dept. of Maritime Studies, 40 Karaoli and Dimitriou St., 185 32, Piraeus, Greece - ttse@ $@$ her.hcmr.gr
}

SUMMARY: Benthic metazoa and stained foraminifera ( $>32 \mu \mathrm{m})$ were studied in relation to prevailing environmental parameters in the Aegean Sea (Sporades Basin and Cretan Sea) and Levantine Basin (Ierapetra Basin) during the METEOR Cruise 40 Leg 3 (December 1997-January 1998). The sampling stations differed in nutrient contents, which were indicative of the oligotrophy of the eastern Mediterranean Sea. Meiobenthic abundance decreased significantly with depth and the total standing stock in the top $6 \mathrm{~cm}$ sediment layer was significantly higher at the northern stations $\left(204-231\right.$ ind./10 $\left.\mathrm{cm}^{2}\right)$. In the abyssal Ierapetra Basin, the abundance for all meiobenthic taxa was minimal $\left(10-26\right.$ ind./10 $\left.\mathrm{cm}^{2}\right)$. Nematodes and foraminifera were dominant and accounted together for $79-93 \%$ of the total abundance. All taxa were concentrated near the surface of the sediment and only nematodes showed a deeper penetration into the sediments in the Sporades Basin. Concentrations of chloroplastic pigments, total organic carbon and total organic nitrogen were higher in the Sporades and Ierapetra Basins than in the Cretan Sea, reflecting: (a) the different productivity levels and, thus, the higher food availability in the former than in the latter; (b) the seasonal accumulation of organic matter from the euphotic zone down to the abyssal trenches; and (c) the transportation of large amounts of sediment and organic matter in the Sporades and Ierapetra Basins, which are located at the mouth of submarine canyons, through riverine inputs, flush flooding, sediment failure and dense shelf water cascading. Meiofaunal abundances in the Aegean Sea were positively correlated with chlorophyll $a$, phaeopigments and chloroplastic pigment equivalent (CPE), and were not correlated with any of the remaining sediment descriptors, thus indicating the dependence of meiofauna on food availability.

Keywords: meiofauna, foraminifera, deep sea, oligotrophy, eastern Mediterranean Sea.

RESUMEN: COMUNIDADES DE MEIOFAUNA Y FORAMINÍFEROS DE MUCHA PROFUNDIDAD A LO LARGO DE UN GRADIENTE DE PRODUCCIÓN PRIMARIA EN EL MEDITERRÁneo ORIENTAL. - Durante la campaña METEOR 40/3 (diciembre 97-enero 98) se estudiaron los metazoos bentónicos y foraminíferos teñidos $(>32 \mu \mathrm{m})$ en relación a parámetros ambientales persistentes en el mar Egeo (Cuencas de Sporades y mar de Creta) y cuenca Levantina (cuenca de Ierapetra). Las estaciones muestreadas se diferenciaron por el contenido en nutrientes, y fueron indicativas de oligotrofia en el este del Mediterráneo. La abundancia del meibentos disminuyó significativamente con la profundidad; y el total de la población en los primeros $6 \mathrm{~cm}$ de sedimento fue significativamente más alto en las estaciones del norte $\left(204-231\right.$ ind./10 $\left.\mathrm{cm}^{2}\right)$. En la cuenca abisal de Ierapetra, la abundancia de todos los taxa del meiobentos fue mínima (10-26 ind./10 $\left.\mathrm{cm}^{2}\right)$. Los nemátodos y foraminíferos fueron dominantes y representaron el 79-93\% de la abundancia total. Todos los taxa se concentraron cerca de la superficie del sedimento y solamente los nemátodos mostraron una penetración más profunda en la cuenca de Sporades. Las concentraciones de pigmentos cloroplásticos, carbón orgánico total y nitrógeno orgánico total fueron más altas en las cuencas de Sporades y Ierapetra que en el mar de Creta, reflejando: (a) los diferentes niveles de productividad y la mayor disponibilidad de alimento en el primero que en el segundo, (b) la acumulación estacional de materia orgánica desde la zona eufótica hacia los canales abisales y (c) el transporte de grandes cantidades de sedimentos y materia orgánica en las primeras áreas, que se encuentran en la boca de cañones submarinos, a través de los influjos de ríos, arrastre por inundaciones, fallos de sedimentos y cascadas de aguas densas de plataforma. Las abundancias de la meiofauna en el mar Egeo estuvieron positivamente correlacionadas con la clorofila a, los feopigmentos y pigmentos cloroplásticos equivalentes y no estuvieron correlacionados con ningún otro descriptor del sedimento, indicando la dependencia de la meiofauna de la disponibilidad de alimento.

Palabras clave: meiofauna, foraminíferos, mar profundo, oligotrofia, Mediterráneo oriental. 


\section{INTRODUCTION}

Deep-sea sediments are food-limited environments, in which benthic communities depend strongly on the amount of organic matter reaching the sea floor (Rowe, 1983; Thiel, 1983; Gooday and Turley, 1990). Since primary production decreases with distance from shore and energy transfer to the sea floor also decreases with increasing water depth, benthic standing stock and biomass also decrease towards more oligotrophic regions and at greater depths (Thiel, 1975). This relationship applies not only to the larger benthic organisms but also to all benthic size classes, including meiofauna, macrofauna and the deposit-feeding megafauna (Thiel, 1983; Lampitt et al., 1986; Sibuet et al., 1989; Vincx et al., 1994). Regarding meiofauna, there is growing evidence that food availability in particular is one of the major factors affecting their abundance and distribution (Thiel, 1983; Gooday et al., 1992; Danovaro et al., 2000; Soltwedel, 2000).

In the eastern Mediterranean, which is one of the most oligotrophic areas in the world (Psarra et $a l ., 2000)$, low productivity rates combined with enhanced organic matter decomposition (due to warm deep waters of $13-14^{\circ} \mathrm{C}$ ) reduce the organic carbon flux to deeper waters. In addition, during certain periods of the year, energy flow and mineralisation processes in the water column are completely regulated by small unicellular organisms, which form the microbial loop and are responsible for the accumulation of DOC in the water column, further minimising the energy transfer to the deeper waters and the benthos (Wassmann et al., 2000). Moreover, analyses of organic matter quality in the eastern Mediterranean indicate that the labile fraction of the organic matter, which may be readily available to meiofaunal organisms, decreases sharply with increasing water depth (Danovaro et al., 1999). As a consequence, meiofaunal abundances and biomasses at bathyal and abyssal depths in the eastern Mediterranean are generally very low (Danovaro et al., 1995; Tselepides and Lampadariou, 2004; Tselepides et al., 2004; Lampadariou and Tselepides, 2006), usually 2 to 25 times lower than those of the more productive western basins (de Bovée et al., 1990). Exceptions to this general pattern are the high meiofaunal abundances found in abyssal trenches (Tselepides and Lampadariou, 2004), and the higher abundances found in areas with seasonally or spatially higher production rates and areas with increased terrigenous organic matter inputs (Danovaro et al., 2000; Lampadariou and Tselepides, 2006).

Starting in 1987, a series of expeditions in the eastern Mediterranean with the R/V Meteor was carried out [METEOR 5 (1987); METEOR 25 (1993); METEOR 40 (1998)] with the general aim of investigating the structure and function of deep-sea benthic communities under highly oligotrophic conditions and warm deep-sea waters. Preliminary results from these expeditions showed that the eastern Mediterranean is an event-driven system which largely depends on lateral transport combined with terrestrial runoff rather than on pelagic production (Kröncke et al., 2003; Tselepides and Lampadariou, 2004). Here we report on the response of meiobenthic communities (both metazoans and foraminiferans) from the METEOR 40 expedition to: (1) the contrasting food supply of two areas with comparable depths, the Sporades Basin (1230 m deep) versus the Cretan Sea (1840 m deep); and (2) the prevailing environmental conditions in the abyssal Ierapetra Basin (southeast of Crete, Levantine Basin, $4260 \mathrm{~m}$ ).

\section{MATERIAL AND METHODS}

\section{Sampling procedure}

Sediment samples were collected from eight stations in the Aegean Sea and Levantine Sea during the R/V Meteor Cruise no 40, leg 3 in December 1997-January 1998 (Fig. 1). The physical and chemical parameters of the sediment, as well as the characteristics of the macrofaunal, viral and bacterial communities, have been presented elsewhere (Danovaro and Serresi, 2000; Kröncke et al., 2003). Three stations were sampled in the Sporades Ba$\sin$ (1230 m deep, North Aegean Sea), three in the Ierapetra Basin (4260 m deep, Levantine Sea) and two in the Cretan Sea (1840 m deep, South Aegean Sea) (Table 1).

Undisturbed sediment samples were collected using a multiple corer with $63.5 \mathrm{~cm}^{2}$ core tubes. Samples for chloroplastic pigments, total organic carbon (TOC) and total organic nitrogen (TON) analyses were collected by subsampling from the multiple-corer and were sliced into 6 sediment layers (0-0.3, 0.3-1, 1-2, 2-4, 4-6 and 6-10 cm). Each layer was homogenised and stored at $-22^{\circ} \mathrm{C}$ for later laboratory analysis. For the grain size analysis, surface sediments $(0-5 \mathrm{~cm})$ were sub- 


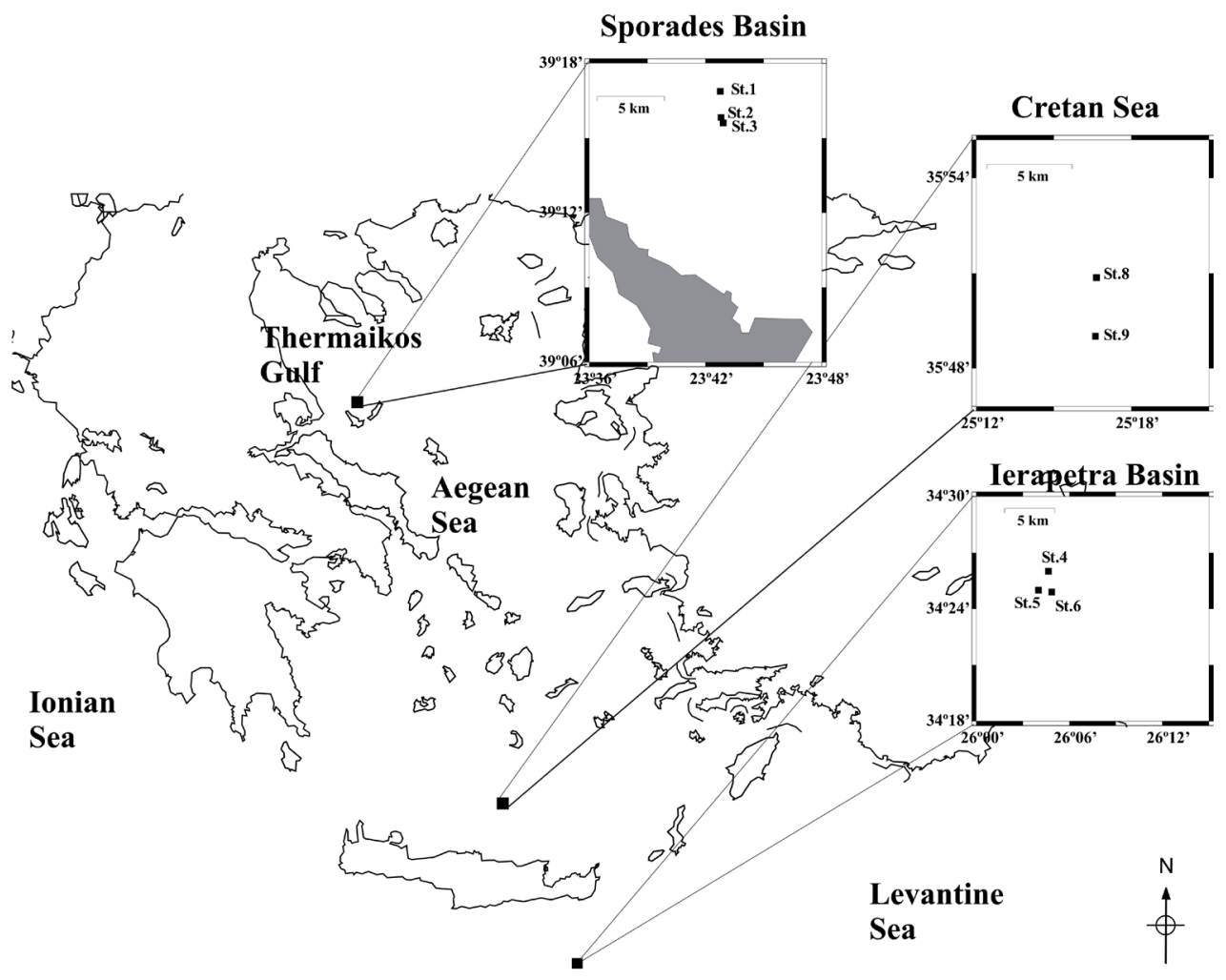

Eastern Mediterranean

FIG. 1. - Sampling area and location of stations (Sporades Basin: stations 1, 2, and 3; Cretan Sea: stations 8 and 9; Ierapetra Basin: stations 4,5 , and 6 ).

TABLE 1. - Station list for the three sampling areas (Temp.: sediment temperature; Eh: redox potential at $1 \mathrm{~cm}$ depth; MD: median diameter of the sediment; $\sigma 1$ : sediment sorting coefficient; S\&C: percentage of silt and clay).

\begin{tabular}{|c|c|c|c|c|c|c|c|c|c|}
\hline & Stations & Latitude (N) & Longitude (E) & Depth (m) & Temp. $\left({ }^{\circ} \mathrm{C}\right)$ & Eh $(\mathrm{mV})$ & $\mathrm{MD}(\mathrm{mm})$ & $\sigma 1$ & $\mathrm{~S} \& \mathrm{C}(\%)$ \\
\hline $\begin{array}{l}\text { Sporades } \\
\text { Basin }\end{array}$ & $\begin{array}{l}1 \\
2 \\
3\end{array}$ & $\begin{array}{l}39^{\circ} 16.53^{\prime} \\
39^{\circ} 15.50^{\prime} \\
39^{\circ} 14.97^{\prime}\end{array}$ & $\begin{array}{l}23^{\circ} 42.46 \\
23^{\circ} 42.48 \\
23^{\circ} 42.55^{\prime}\end{array}$ & $\begin{array}{l}1250 \\
1221 \\
1224\end{array}$ & $\begin{array}{l}13.0 \\
13.1 \\
13.1\end{array}$ & $\begin{array}{l}461 \\
526 \\
528\end{array}$ & $\begin{array}{l}0.012 \\
0.010 \\
0.003\end{array}$ & $\begin{array}{l}2.4 \\
2.1 \\
2.7\end{array}$ & $\begin{array}{l}99.4 \\
99.2 \\
99.4\end{array}$ \\
\hline $\begin{array}{l}\text { Ierapetra } \\
\text { Basin }\end{array}$ & $\begin{array}{l}4 \\
5 \\
6\end{array}$ & $\begin{array}{l}34^{\circ} 26.01 \\
34^{\circ} 25.00 \\
34^{\circ} 24.54\end{array}$ & $\begin{array}{l}26^{\circ} 03.99^{\prime} \\
26^{\circ} 04.00 \\
26^{\circ} 04.52\end{array}$ & $\begin{array}{l}4157 \\
4260 \\
4261\end{array}$ & $\begin{array}{l}13.9 \\
13.8 \\
13.8\end{array}$ & $\begin{array}{l}466 \\
508 \\
503\end{array}$ & $\begin{array}{l}0.011 \\
0.006 \\
0.020\end{array}$ & $\begin{array}{l}1.0 \\
1.7 \\
1.6\end{array}$ & $\begin{array}{l}99.9 \\
96.2 \\
98.2\end{array}$ \\
\hline $\begin{array}{l}\text { Cretan } \\
\text { Sea }\end{array}$ & $\begin{array}{l}8 \\
9\end{array}$ & $\begin{array}{l}35^{\circ} 49.01 \\
35^{\circ} 50.52^{\prime}\end{array}$ & $\begin{array}{l}25^{\circ} 15.97^{\prime} \\
25^{\circ} 15.99^{\prime}\end{array}$ & $\begin{array}{l}1840 \\
1840\end{array}$ & $\begin{array}{l}14.2 \\
13.7\end{array}$ & $\begin{array}{l}439 \\
471\end{array}$ & $\begin{array}{l}0.028 \\
0.005\end{array}$ & $\begin{array}{l}1.6 \\
1.0\end{array}$ & $\begin{array}{l}96.4 \\
98.2\end{array}$ \\
\hline
\end{tabular}

sampled from the cores and stored at $-22^{\circ} \mathrm{C}$ for later analysis.

For meiofaunal analyses, three replicate samples which were sliced into 6 sediment layers $(0-1$, 1-2, 2-4, 4-6 and 6-10 cm) were collected. Immediately after slicing, they were placed for $15 \mathrm{~min}$. in a $\mathrm{MgCl}_{2}$ solution for tissue relaxation and then fixed with a neutralised formaldehyde solution to a final concentration of $4 \%$.

Redox Potential (Eh) of the sediment was measured (in $\mathrm{mV}$ ) on board immediately after sampling (at $1 \mathrm{~cm}$ intervals down to $20 \mathrm{~cm}$ sediment depth) with the use of calibrated combined electrodes (Russell pH, Scotland, type no. CMPT 11/280/SA1.5).

\section{Analytical procedures}

Chlorophyll $a$ and phaeopigment concentrations were determined with a TURNER 112 fluorometer (Lorenzen and Jeffrey, 1980) and using 90\% acetone extractant. Phaeopigments were estimated by acidification with $0.1 \mathrm{~N} \mathrm{HCl}$. The fluorometer was calibrated using an acetone extract of pure chlorophyll $a$ from the algae Anacystis nidulans obtained from SIGMA. Chloroplastic pigment 
TABLE 2. - Mean abundance (individuals per $10 \mathrm{~cm}^{2} \pm \mathrm{SD}$ ) of all meiobenthic taxa in the top $6 \mathrm{~cm}$ of the sediments. Others include taxa (Tardigrada, Tanaidacea, Oligochaeta, Echinodermada, Mollusca, Nemertina and Sipuncula) which occurred only occasionally and in very low numbers.

\begin{tabular}{|c|c|c|c|c|c|c|c|c|c|c|c|c|c|c|c|}
\hline & & & Sporade & s Basin & & & & & Ierapetra Basin & & & & Cret: & n Sea & \\
\hline & St.1 & SD & St.2 & SD & St.3 & $\mathrm{SD}$ & St. 4 & SD & St.5 SD & St.6 & SD & St. 8 & $\mathrm{SD}$ & St.9 & SD \\
\hline Nematoda & 142 & \pm 80 & $184 \pm$ & $=52$ & $143 \pm$ & \pm 46 & $10 \pm$ & $=5$ & $15 \pm 4$ & $18 \pm$ & 6 & $51 \pm$ & $=32$ & 88 & \pm 74 \\
\hline Foraminifera & 46 & \pm 19 & $37 \pm$ & $=9$ & $47 \pm$ & \pm 10 & $1 \pm$ & $=1$ & $5 \pm 1$ & $5=$ & 1 & $14 \pm$ & $=1$ & 28 & \pm 28 \\
\hline Copepoda & 21 & \pm 2 & $18 \pm$ & $=2$ & $20 \pm$ & \pm 2 & $0 \pm$ & $=0$ & $3 \pm 1$ & $4=$ & 1 & $8 \pm$ & $=1$ & 6 & \pm 2 \\
\hline Nauplii & 6 & \pm 3 & $8 \pm$ & $=2$ & $8 \pm$ & \pm 5 & $0 \pm$ & 0 & $0 \pm 0$ & $1=$ & 0 & $3 \pm$ & $=2$ & 2 & \pm 3 \\
\hline Polychaeta & 5 & \pm 1 & $6 \pm$ & $=2$ & $8 \pm$ & \pm 2 & $0 \pm$ & \pm 0 & $0 \pm 0$ & $0=$ & 0 & $2 \pm$ & $=1$ & 2 & \pm 1 \\
\hline Turbellaria & 3 & \pm 1 & $2 \pm$ & $=1$ & $1 \pm$ & \pm 1 & $0 \pm$ & 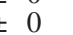 & $0 \pm 0$ & $0=$ & 0 & $1 \pm$ & $=0$ & 0 & \pm 0 \\
\hline Kinoryncha & 1 & \pm 0 & $0 \pm$ & $=0$ & $2 \pm$ & \pm 1 & $0 \pm$ & \pm 0 & $0 \pm 0$ & $0=$ & 0 & $0 \pm$ & $=0$ & 1 & \pm 1 \\
\hline Ostracoda & 2 & \pm 0 & $1 \pm$ & & $2 \pm$ & \pm 1 & $0 \pm$ & \pm 0 & $0 \pm 0$ & $0=$ & 0 & $1 \pm$ & $=0$ & 0 & \pm 0 \\
\hline Others & 2 & \pm 1 & $2 \pm$ & $=1$ & $5 \pm$ & \pm 4 & $0 \pm$ & \pm 1 & $0 \pm 0$ & $1=$ & 2 & $1 \pm$ & $=1$ & 1 & \pm 0 \\
\hline Total & 228 & \pm 99 & $258 \pm$ & $=59$ & $235 \pm$ & \pm 30 & $11 \pm$ & \pm 6 & $23 \pm 5$ & $29=$ & 5 & $80 \pm$ & $=35$ & 127 & \pm 108 \\
\hline
\end{tabular}

equivalents (CPE) were considered as the sum of chlorophyll $a$ and phaeopigments content.

TOC and TON concentrations were measured with a Perkin Elmer CHN 2400 analyser (Hedges and Stern, 1984).

Grain size analysis was performed according to Buchanan (1984). The median diameter (MD) and the graphic sorting coefficient $(\sigma 1)$ of the sediments were calculated after Folk (1966). The silt-clay percentage fraction was also calculated.

\section{Meiofaunal analyses}

In the laboratory, meiobenthic samples were stained with Rose Bengal solution $\left(0.5 \mathrm{~g} \mathrm{l}^{-1}\right)$ and sieved through a $32 \mu \mathrm{m}$ mesh. The fauna retained on the $32 \mu \mathrm{m}$ mesh was extracted by triplicate centrifugation in Ludox TM (density $1.15 \mathrm{~g} \mathrm{~cm}^{-3}$ ). All meiobenthic metazoans and soft-shelled foraminiferans in the supernatant, as well as the stained hard-shelled foraminiferans from the residual sediment, were counted and identified to major taxa using a WILD stereomicroscope.

\section{Statistical analyses}

Differences in environmental and faunal parameters were assessed by one-way analysis of variance (one-way ANOVA), followed by pairwise comparisons based on the Tukey honest significant difference test (Tukey HSD). The nonparametric Kruskal-Wallis test was used when data did not meet the assumption of normality or equality of variances after being log-transformed. Spearman's rank correlation coefficient was used to assess the relationships between meiofaunal and abiotic descriptors. Non-metric multidimensional scaling (MDS) ordination was based on the BrayCurtis similarity and square-root transformed abundance data. Univariate and multivariate analyses were performed with the STATISTICA 6.0 and the PRIMER version 6.1.3 (Clarke and Warwick, 1994) packages, respectively.

\section{RESULTS}

\section{Sediment characteristics and changes in Redox potential}

Silty superficial sediments characterised all investigated stations (Table 1). Median grain size ranged from $0.003 \mathrm{~mm}$ (Station 3, Sporades Basin) to $0.028 \mathrm{~mm}$ (Stations 8 and 10, Cretan Sea). The silt and clay fraction varied on average from $96 \%$ (Station 8, Cretan Sea) to 99\% (Stations 1, 2, 3, Sporades Basin). Northern stations (1, 2 and 3, Sporades Basin) were characterised by a sorting coefficient $(\sigma 1)$ higher than 2. Redox potential (Eh) in the top 1 $\mathrm{cm}$ sediment layer was relatively high at all stations, ranging from 461 to $528 \mathrm{mV}$ in the Sporades Basin, from 439 to $471 \mathrm{mV}$ in the Cretan Sea and from 466 to $508 \mathrm{mV}$ in the Ierapetra Basin. Sediment temperature was relatively constant at all stations, ranging between 13 and $14^{\circ} \mathrm{C}$.

\section{Distribution and structure of meiobenthos and relationships with the environment}

Standing stock of the total meiobenthos in the top $6 \mathrm{~cm}$ sediment layer varied significantly (Kruskal Wallis Test, $P<0.01)$ among stations, decreasing 


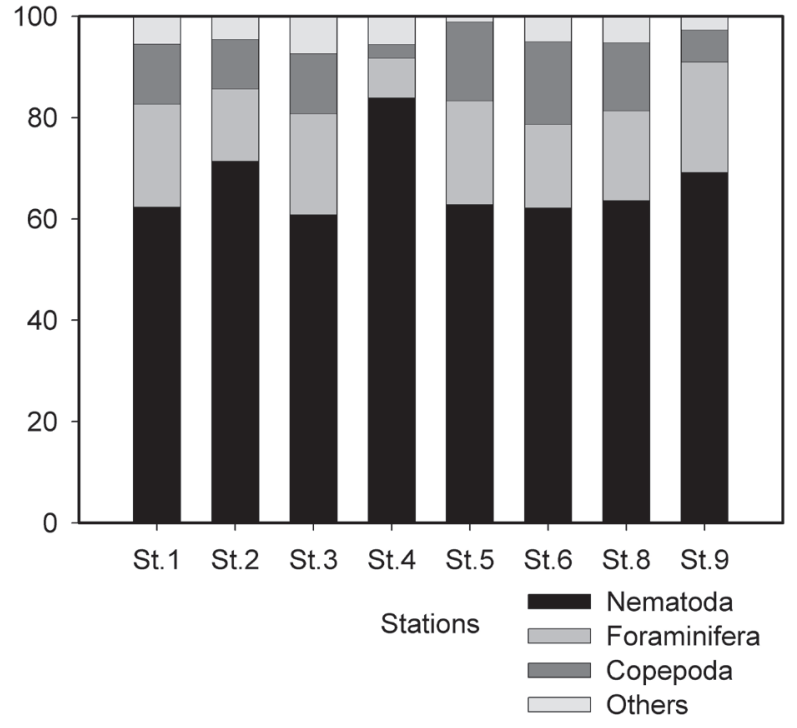

FIG. 2. - Average contribution (\%) of different groups to the total meiobenthos in the three study areas.

sharply with increasing depth. The highest values were recorded in the Sporades Basin (228-258 ind. $/ 10 \mathrm{~cm}^{2}$ ), while in the abyssal Ierapetra Basin, the abundance of all meiobenthic taxa was very low (11-29 ind./10 $\mathrm{cm}^{2}$ ) (Table 2).

Nematodes and foraminifera were the most abundant groups, accounting together for $79-92 \%$ of the total meiofaunal abundance (Table 2, Fig. 2). Nematodes were the dominant taxon at all the stations examined (61-84\%), with abundances ranging from $10 \pm 5$ (St. 4, Ierapetra Basin) to $184 \pm 52$ ind./10 $\mathrm{cm}^{2}$ (St. 2, Sporades Basin). Foraminifera were the second most abundant taxon, accounting for $8-22 \%$. Their abundance ranged from $1 \pm 1$ (St. 4, Ierapetra Basin) to $47 \pm 10$ ind. $/ 10 \mathrm{~cm}^{2}$ (St. 3, Sporades Basin). Harpacticoid copepods (including nauplii) contrib-

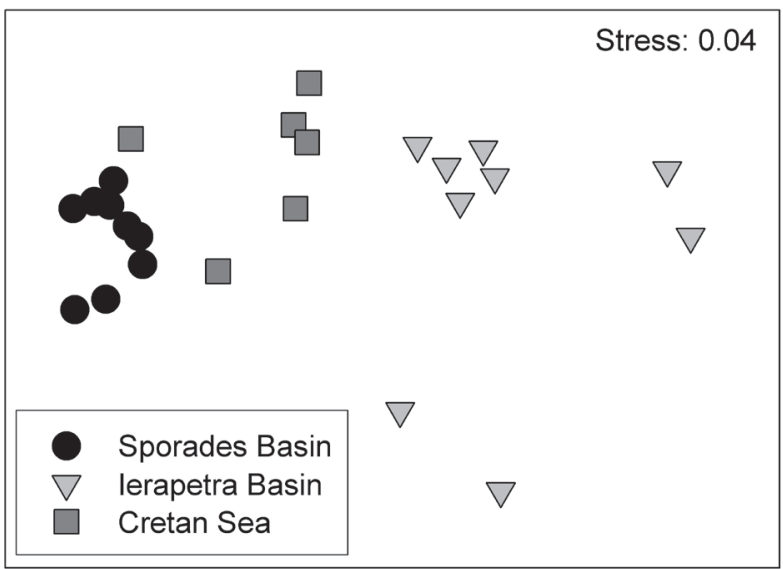

FIG. 4. - Non-parametric multidimensional scaling (MDS) ordination of replicate samples from the three sapling areas.

uted $3-16 \%$ to the total abundance and polychaetes accounted for less than $4 \%$ (Table 2). Turbellarians and kinorynchs represented always less than $2 \%$ of the community. The remaining taxa (i.e. nemertins, molluscs, ostracods and other minor groups) contributed together approximately $3.5 \%$ to the total meiobenthos (Table 2).

As a general rule, all meiobenthic groups were concentrated in the top $1 \mathrm{~cm}$ layer of the sediment, the only exception being nematodes, which showed a much deeper penetration in the sediment in the Sporades Basin (Fig. 3).

Samples from the same basin were grouped closely together in the MDS plot (Fig. 4), the only exception being 9c (Cretan Sea), which lay close to the Sporades Basin stations. The main grouping factors were depth and Eh (BIOENV: R=0.82), as the shallower Sporades Basin was clearly separated from the much deeper Ierapetra Basin (one-way ANOSIM, $P<0.001$ ).
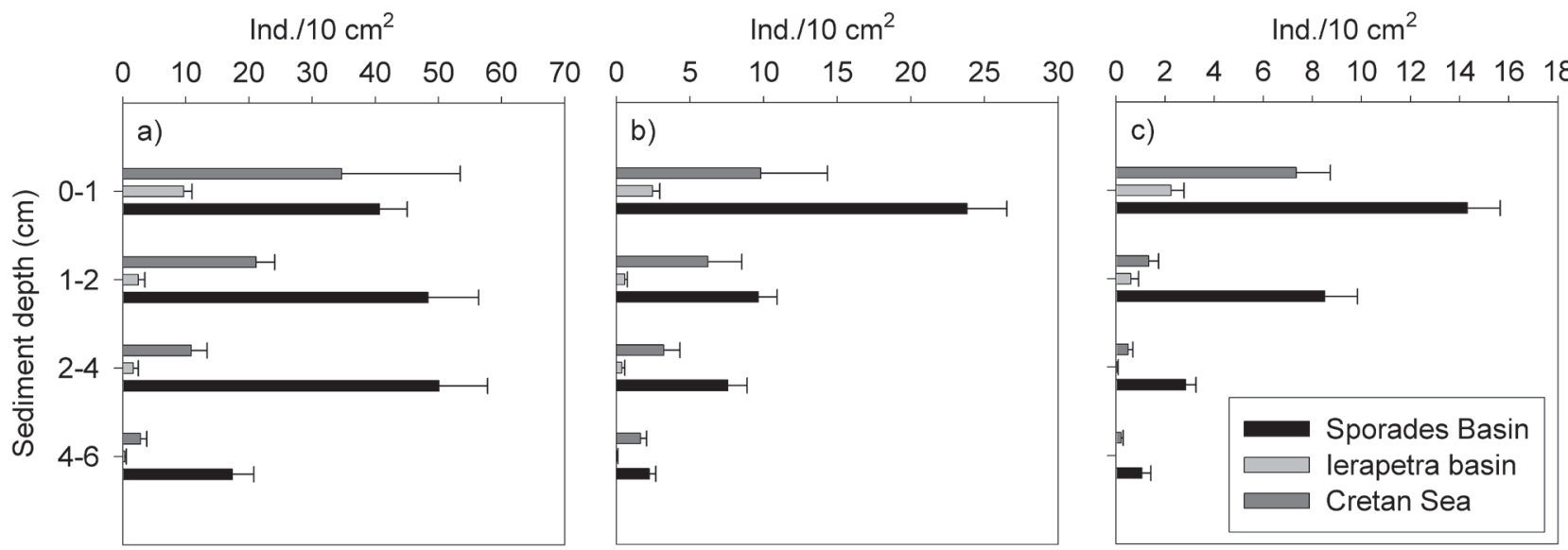

FIG. 3. - Mean vertical (individuals per $10 \mathrm{~cm}^{2} \pm \mathrm{SE}$ ) of (a) nematodes, (b) foraminifera and (c) copepods (adults and nauplii) at the three sampling areas. 
TABLE 3. - Spearman correlation coefficient between environmental variables and meiobenthic groups (TOC: total organic carbon; TON: total organic nitrogen; Chl $a$ : chlorophyll $a$; Phaeop.: phaeopigments; CPE: chloroplastic pigments equivalent; Temp.: sediment temperature; Eh: redox potential; MD: median diameter of the sediment; $\sigma 1$ : sediment sorting coefficient; S\&C: percentage of silt and clay).

\begin{tabular}{|c|c|c|c|c|c|c|c|c|c|c|c|c|c|}
\hline & TOC & TON & TOC/TON & Chl $a$ & Phaeop. & CPE & Chl.a/CPE & Depth & Temp. & Eh & MD & $\sigma 1$ & $\mathrm{~S} \& \mathrm{C}$ \\
\hline Nematoda & $0.76^{*}$ & $0.74 *$ & $-0.81 *$ & 0.33 & 0.52 & 0.45 & -0.52 & $-0.90 * *$ & $-0.77 *$ & 0.38 & -0.31 & 0.66 & 0.19 \\
\hline Foraminifera & 0.69 & 0.67 & $-0.74 *$ & 0.26 & 0.55 & 0.45 & -0.62 & $-0.83^{*}$ & $-0.81 *$ & 0.29 & -0.33 & $0.73 *$ & 0.26 \\
\hline Copepoda & $0.74 *$ & $0.71 *$ & -0.69 & 0.26 & 0.60 & 0.48 & -0.62 & $-0.80 *$ & $-0.75 *$ & 0.07 & -0.07 & $0.76 *$ & 0.21 \\
\hline Nauplii & $0.74 *$ & $0.71 *$ & $-0.76 *$ & 0.33 & 0.48 & 0.40 & -0.50 & $-0.87 * *$ & -0.67 & 0.33 & -0.24 & $0.76^{*}$ & 0.21 \\
\hline Polychaeta & $0.74 *$ & $0.71 *$ & $-0.76^{*}$ & 0.33 & 0.48 & 0.40 & -0.50 & $-0.87 * *$ & -0.67 & 0.33 & -0.24 & $0.76^{*}$ & 0.21 \\
\hline Turbellaria & $0.75^{*}$ & $0.72 *$ & -0.68 & 0.28 & 0.59 & 0.47 & -0.59 & $-0.84 * *$ & $-0.73 *$ & 0.01 & 0.02 & 0.67 & 0.25 \\
\hline Kinoryncha & 0.36 & 0.40 & -0.69 & 0.02 & 0.28 & 0.14 & -0.54 & -0.70 & $-0.82 *$ & 0.34 & -0.68 & 0.52 & 0.55 \\
\hline Ostracoda & 0.63 & 0.63 & $-0.76^{*}$ & 0.17 & 0.39 & 0.27 & -0.61 & $-0.90 * *$ & -0.69 & 0.17 & -0.24 & $0.75 *$ & 0.34 \\
\hline Others & $0.79 *$ & 0.69 & -0.57 & 0.62 & 0.62 & 0.60 & -0.19 & $-0.73^{*}$ & -0.66 & 0.38 & -0.10 & $0.72 *$ & 0.45 \\
\hline
\end{tabular}

$* P \leq 0.05 ; * * P \leq 0.01$

Most meiobenthic groups were negatively correlated with depth, while nematodes, copepods, nauplii, polychaetes and turbellaria were positively correlated with total organic carbon and nitrogen (Table 3). A significant positive correlation between the sorting coefficient of the sediment and most groups, with the exception of nematodes, turbellaria and kinorynchs, was also found (Table 3).

\section{DISCUSSION}

In the present study, several trends regarding the distribution patterns of meiofaunal communities under the highly oligotrophic conditions of the eastern Mediterranean are evident. Meiofaunal abundances significantly decreased with increasing water depth. They were also much higher in the northern (Sporades) compared to the southern (Cretan and Ierapetra) basins, with average abundances in the Sporades Basin being almost double than those in the Cretan Sea (215-93 ind. $/ 10 \mathrm{~cm}^{2}$, respectively) and 10 times higher than the extremely low values found in the southernmost Ierapetra Basin (10-26 ind./10 cm²). Meiofauna abundances were also much lower below the surface of the sediments and only nematodes showed a deeper penetration in the sediments in the Sporades Basin, following the vertical profiles of phaeopigments and bacteria.

The abundances recorded in this study are in accordance with those of other studies in bathyal and abyssal sediments of the eastern Mediterranean (Danovaro et al., 1995; Danovaro et al., 2000; Tselepides and Lampadariou, 2004; Tselepides et al., 2004; Lampadariou and Tselepides, 2006) but much lower than those of other deep-sea areas with a similar water depth (Shirayama, 1984a; Soetaert et al., 1991; Vincx et al., 1994). This general trend of very low meiofaunal abundances in the eastern Mediterranean is mainly related to the prevailing oligotrophic conditions and is clearly evident when the northern and southern stations of the Aegean Sea are compared. The South Aegean, one of the most oligotrophic regions of the Mediterranean Sea, is characterised by extremely low productivity rates coupled with high temperatures, strong summer stratification of the water column and minimal quantities of organic matter in bathyal sediments (Psarra et al., 2000; Tselepides et al., 2000). In contrast, the North Aegean is more productive, mainly due to the influx of nutrient-rich Black Sea surface waters entering through the Dardanelles Straits and riverine outflows (Poulos et al., 1997). In addition to this, the deep Sporades Basin is at the south end of Thermaikos Gulf, acting as a deposition centre for sediments originating from riverine inputs and nepheloid layer detachments over the continental shelf (Lykousis and Chronis, 1989). This higher productivity of the North Aegean clearly results in high pigment concentrations in the sediment (chlorophyll $a$, phaeopigments and $\mathrm{CPE}$ ), which in turn results in much higher meiofaunal abundances in the Sporades Basin, as can also be seen in the significant correlations between abundances and pigment concentrations. These results are in line with previous research in the area. For example, strong differences in meiofaunal standing stocks between bathyal stations of the North Aegean and stations of similar depth of the South Aegean have been reported by Lampadariou and Tselepides (2006), who also attributed them to differences in surface productivity and food input to the benthos.

The very low abundances found in the Ierapetra Basin follow the general trend of decreasing meiofauna abundance with increasing water depth (de Bovée et al., 1990; Vincx et al., 1994). One of the 
most important factors varying with depth is the supply of organic matter to the sea floor, and the low food supply at abyssal and hadal depths results in reduced macrofaunal and meiofaunal abundance and biomass. Exceptions from the above rule are upwelling areas, characterised by high seasonal down-slope fluxes of organic matter as well as areas where-due to seafloor morphology or hydrodynamic processes-particulate organic carbon may be accumulated on the ocean floor. For example, Danovaro et al. (2002) reported meiofaunal densities 1 or 2 orders of magnitude higher in the Atacama Trench (7800 $\mathrm{m}$ deep) than in the much shallower surrounding areas (1050-1355 m deep), and Tselepides and Lampadariou (2004) reported much higher meiofaunal abundances in the Hellenic and Pliny Trenches (3744-4617 $\mathrm{m}$ deep) than at the shallower ( $<3000 \mathrm{~m}$ deep) nearby abyssal sites. These high values were attributed to the function of trenches as abyssal traps for particulate organic matter, as indicated by the very high phaeopigment concentrations and the enhanced activity and biomass of microbial communities (Boetius et al., 1996). Food quality is another factor that may account for the lower abundances found in the Ierapetra Basin. Analysis of the biogeochemical composition of sedimentary organic matter has shown that the eastern Mediterranean is a strongly protein-depleted ecosystem and that the concentration of proteins plays a key role in determining its trophic properties (Danovaro et al., 1999). In contrast, carbohydrates, which are common for oligotrophic environments, are composed mainly of refractory compounds with low degradation rates. In the Ierapetra Basin, the protein/carbohydrate ratio suggested that the quality of organic matter was very low during winter (Danovaro and Serresi, 2000). We postulate that the labile compounds from the high-quality, fresh organic matter accumulated during the summer are easily consumed, resulting in surprisingly high meiofaunal abundances. Then, the remaining organic matter during the winter is dominated by less soluble, refractory compounds behaving as an organic carbon reservoir that is difficult for benthic meiofauna to degrade, thus limiting their standing stocks until a further down-slope flux of fresh labile organic matter occurs.

The vertical distribution of meiofauna within the sediment has been investigated by many authors. A decrease in meiofauna abundance has been generally observed, although in some cases a maximum was found in deeper layers (Thiel, 1983 and refer- ences therein). One of the main factors influencing the vertical penetration of meiofauna into deepsea sediments is the oxygenation of the sediment column (Shirayama, 1984b). In more productive areas, however, food may be more important since it will penetrate deeper into the sediment due to vertical mixing and bioturbation by larger animals (Thiel, 1983; Lambshead et al., 1995). In the present study, the high Eh values measured in all three areas-although not a direct measurement of oxygenation-suggest that other site-specific factors may be important for the observed vertical distribution patterns of meiofauna. In fact, the significantly deeper penetration of meiofauna in the Sporades Basin and the Cretan Sea and the relatively high abundances of nematodes in the 2-4 cm layer in the Sporades Basin clearly fit the vertical profiles of phaeopigments and bacterial density in the sediment (Danovaro and Serresi, 2000), thus suggesting that the depth of food penetration may be more important for meiofauna than oxygen (Lambshead et al., 1995).

Regarding foraminifera standing stocks, data from the eastern Mediterranean are practically nonexistent. However, the densities found during this investigation, especially those from the Sporades Basin, were similar to those previously found in the western Ionian (Tselepides et al., 2004) as well as in other deep-sea areas (Hughes et al., 2000). Foraminifera densities at bathyal and abyssal depths are usually less than 200 ind./10 $\mathrm{cm}^{2}$ (Thiel, 1975; Gooday, 1986), although much higher values have been reported from areas with a higher carbon input (Fariduddin and Loubere, 1997). Some foraminifera may rapidly and directly incorporate part of a bloom sedimentation, which suggests that they play an important role in the breakdown of fresh detrital material by benthic food webs (Moodley et al., 2000). Thus, the comparison of the two major meiobenthic components (i.e. nematodes and foraminifera) suggests that both groups are similarly sensitive to food supply and that they show a similar response to carbon limitation in terms of standing stock.

In the deep-sea, short-term seasonal changes that may affect benthic populations, such as the deposition of large amounts of phytodetritus, are known to occur quite often (Tyler, 1988; Pfannkuche, 1993; Smith et al., 1996). Longer time-series measurements over decadal scales, although quite rare, have also successfully attributed changes in benthic communities to temporal changes in phytodetrital fluxes (Smith and Druffel, 1998; Billett et al., 2001). In 


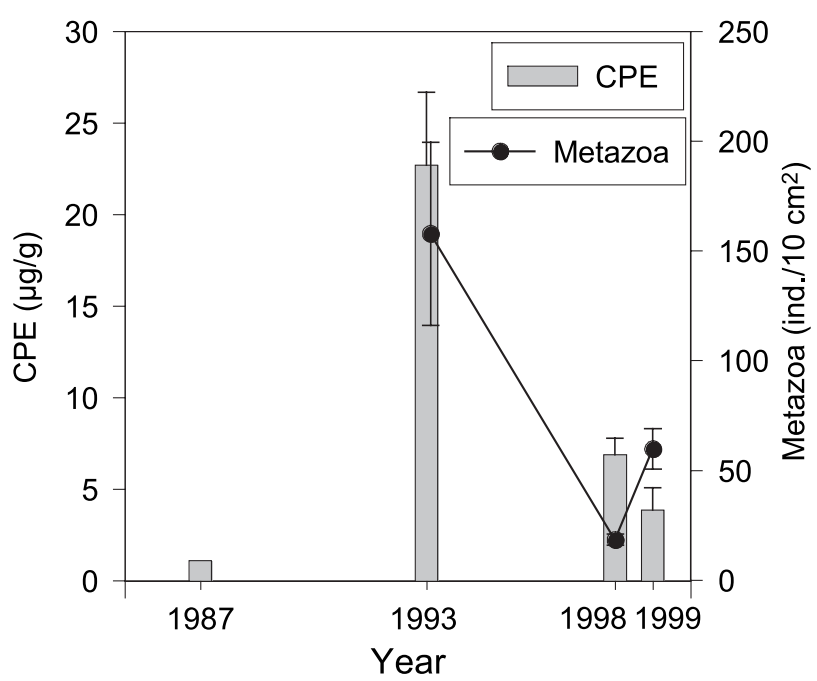

FIG. 5. - Time series measurements of chloroplastic pigment equivalent (CPE) and metazoan meiofauna abundances from different cruises in the Ierapetra Basin [1987: Meteor No 5/1 (Tselepides and Lampadariou, unpublished data); 1993: Meteor No 25/1 (Tselepides and Lampadariou, 2004); 1998: Meteor No 40/3 (Present study); 1999: Aegaeo Trans-Mediterranean cruise (Danovaro et al., 2008)].

the eastern Mediterranean, low food availability at $4000 \mathrm{~m}$ in the abyssal Ierapetra Basin, as indicated by the low concentrations of CPE in 1987, was followed by very high concentrations in 1993 before dropping near to background values in 1998 and 1999 (Fig. 5). This fluctuation was probably due to a dramatic change in the hydrography of the Cretan Sea as of 1992, which caused an increasing outflow of nutrient rich water masses into the Levantine Basin (Roether et al., 1996; Theocharis et al., 1999). This event affected not only the abundance and composition of the planktonic assemblages (Weikert et al., 2001) but also the macro- and meiobenthic communities (Kröncke et al., 2003; Tselepides and Lampadariou, 2004). The still high winter concentrations of phaeopigments in 1998 compared to 1987 may suggest that the induced changes are longer-term and also that organic material may accumulate in the Ierapetra Basin. The above results are a clear indication that the eastern Mediterranean is an event-driven system, with irregular high food ingressions into the sea floor, which plays a major role in the structure and function of benthic communities.

\section{ACKNOWLEDGMENTS}

We are grateful to Dr. Michael Türkay for inviting us to participate in the METEOR expeditions to the eastern Mediterranean, to the captain and crew of R/V Meteor and to our colleagues N. Papadopou- lou, D. Podaras and T. Polychronaki for assistance with sampling. This work was jointly supported and funded by the European Commission's Marine Science and Technology (MAST) Program, under the MTP-MATER project (contract MAST III-CT960051), the Deutsche Forschungsgemeinschaft and the Ministry of Development of Greece (General Secretariat of Research and Technology).

\section{REFERENCES}

Billett, D.S.M., B.J. Bett, A.L. Rice, M.H. Thurston, J. Galéron, M. Sibuet and G.A. Wolff. - 2001. Long-term change in the megabenthos of the Porcupine Abyssal Plain (NE Atlantic). Prog. Oceanogr., 50: 325-348.

Boetius, A., S. Scheibe, A. Tselepides and H. Thiel. - 1996. Microbial biomass and activities in deep sea sediments of the Eastern Mediterranean: trenches are benthic hotspots. Deep-Sea Research I. 43: 1439-1460.

Buchanan, J.B. - 1984. Sediment analysis. In: N.A. Holme and A.D. McIntyre (eds.), Methods for the study of Marine Benthos, pp. 41-65. Blackwell Scientific Publications, Oxford.

Clarke, K.R. and R.M. Warwick. - 1994. Similarity-based testing for community pattern: the two-way layout with no replication. Mar. Biol., 118: 167-176.

Danovaro, R. and M. Serresi. - 2000. Viral density and virus-tobacterium ratio in deep-sea sediments of the eastern Mediterranean. Appl. Environ. Microbiol., 66: 1857-1861.

Danovaro, R., A. Tselepides, A. Otegui and N. Della Croce. - 2000 Dynamics of meiofaunal assemblages on the continental shelf and deep-sea sediments of the Cretan Sea (NE Mediterranean): relationships with seasonal changes in food supply. Prog. Oceanogr., 46: 367-400.

Danovaro, R., C. Gambi and N. Della Croce. - 2002. Meiofauna hotspot in the Atacama Trench, eastern South Pacific Ocean. Deep-Sea Res. I., 49: 843-857.

Danovaro, R., D. Marrale, N. Della Croce, P. Parodi and M. Fabiano. - 1999. Biochemical composition of sedimentary organic matter and bacterial distribution in the Aegean Sea: trophic state and pelagic-benthic coupling. J. Sea Res., 42: 117-129.

Danovaro, R., N. Della Croce, A. Eleftheriou, M. Fabiano, N. Papadopoulou, C. Smith and A. Tselepides. - 1995. Meiofauna of the deep Eastern Mediterranean Sea: distribution, and abundance in relation to bacterial biomass, organic matter composition and other environmental factors. Prog. Oceanogr., 36: 329-341.

Danovaro, R., C. Gambi, N. Lampadariou and A. Tselepides. - 2008. Deep-sea nematode biodiversity in the Mediterranean basin: testing for longitudinal, bathymetric and energetic gradients. Ecography, 31: 231-244.

de Bovée, F., L.D. Guidi and J. Soyer. - 1990. Quantitative distribution of deep-sea meiobenthos in the northwestern Mediterranean (Gulf of Lions). Cont. Shelf Res., 10: 1123-1145.

Fariduddin, M. and P. Loubere. - 1997. The surface ocean productivity response of deeper water benthic foraminifera in the Atlantic Ocean. Mar. Micropaleontol., 32: 289-310.

Folk, R.L. - 1966. A review of grain-size parameters. Sedimentology, 6: 73-93.

Gooday, A.J. - 1986. Meiofaunal foraminiferans from the bathyal Porcupine Seabight: size structure, taxonomic composition, species diversity and vertical distribution in the sediment. Deep-Sea Res., 33: 1345-1372.

Gooday, A.J. and C.M. Turley. - 1990. Responses by benthic organisms to input of organic material to the ocean floor: a review. Philos. Trans. R. Soc. Lond. A., 331: 119-138.

Gooday, A.J., L.A. Levin, P. Linke and T. Heeger. - 1992. The role of benthic foraminifera in deep-sea food webs and carbon cycling. In: G.T. Rowe and V. Pariente (eds.), Deep-Sea food chains and the global carbon cycle, pp. 63-91. Kluwer Academic Publishers.

Hedges, J.I. and J.H. Stern. - 1984. Carbon and nitrogen determi- 
nation of carbonate-containing solids. Limnol. Oceanogr., 29: 657-663.

Hughes, J.A., A.J. Gooday and J.W. Murray. - 2000. Distribution of live benthic foraminifera at three oceanographically dissimilar sites in the northeast Atlantic: prelinary results. Hydrobiologia, 440: $227-238$.

Kröncke, I., M. Türkay and D. Fiege. - 2003. Macrofauna communities in the Eastern Mediterranean deep sea. Mar. Ecol., 24 193-216.

Lambshead, P.J.D., T.J. Ferrero and G.A. Wolff. - 1995. Comparison of the vertical distribution of nematodes from two contrasting abyssal sites in the northeast Atlantic subject to different seasonal inputs of phytodetritus. Int. Revue Ges. Hydrobiol., 80: 327-332.

Lampadariou, N. and A. Tselepides. - 2006. Spatial variability of meiofaunal communities at areas of contrasting depth and productivity in the Aegean Sea (NE Mediterranean). Prog. Oceanogr., 69: 19-36.

Lampitt, R.S., D.S.M. Billett and A.L. Rice. - 1986. Biomass of the invertebrate megabenthos from 500 to $4100 \mathrm{~m}$ in the norteast Atlantic Ocean. Mar. Biol., 93: 69-81.

Lorenzen, C. and J. Jeffrey. - 1980. Determination of chlorophyll in sea water. UNESCO.

Lykousis, V and G. Chronis. - 1989. Mechanisms of sediment transport and deposition: sediment sequences and accumulation during the Holocene on the Thermaikos Plateau, the continental slope and basin (Sporades Basin), northwestern Aegean Sea, Greece. Mar. Geol., 87: 15-26.

Moodley, L., H.T.S. Boschker, J.J. Middelburg, R. Pel, P.M.J. Herman, E. de Deckere and C.H.R. Heip. - 2000. Ecological significance of benthic foraminifera: C-13 labelling experiments. Mar. Ecol. Prog. Ser. 202: 289-295.

Pfannkuche, O. - 1993. Benthic response to the sedimentation of particulate organic matter at the BIOTRANS station $47^{\circ} \mathrm{N}$ $20^{\circ}$ W. Deep-Sea Res. II, 40: 135-149.

Poulos, S.E., P.G. Drakopoulos and M.B. Collins. - 1997. Seasonal variability in sea surface oceanographic conditions in the Aegean Sea (Eastern Mediterranean): an overview. J. Mar. Syst., 13: 225-244.

Psarra, S., A. Tselepides and L. Ignatiades. - 2000. Primary productvity in the oligotrophic Cretan Sea (NE Mediterranean): seasonal and interannual variability. Prog. Oceanogr., 46: 187-204.

Roether, W., B.B. Manc, B. Klein, D. Bregant, D. Georgopoulos, V. Beitzel, V. Kocacevic and A. Luchetta. - 1996. Recent changes in eastern Mediterranean Deep Waters. Science, 271: 333-335.

Rowe, G.T. -1983 . Biomass and production of the deep-sea macrobenthos. In: G. Rowe (ed.), Deep-sea biology, pp. 97-121. Wiley Interscience, New York.

Shirayama, Y. - 1984a. The abundance of deep sea meiobenthos in the western Pacific in relation to environmental factors. Oceanol. Acta, 7: 113-121.

Shirayama, Y. - 1984b. Vertical distribution of meiobenthos in the sediment profile in bathyal, abyssal and hadal deep sea systems of the western Pacific. Oceanol. Acta, 7: 123-129.
Sibuet, M., C.E. Lamberti, R. Chesselet and L. Laubfer. - 1989. Density of the major size groups of benthic fauna and trophic input in deep basins of the Atlantic Ocean. J. Mar. Res., 47: 851-867.

Smith, C.R., D.J. Hoover, S.E. Doan, R.H. Pope, D.J. Demaster, F.C. Dobbs and A. Altabet. - 1996. Phytodetritus at the abyssal seafloor across $10^{\circ}$ of latitude in the central equatorial Pacific. Deep-Sea Res. II, 43: 1309-1338.

Smith, K.L. and E.R.M. Druffel. - 1998. Long time-series monitoring of an abyssal site in the NE Pacific: an introduction. DeepSea Res. II, 45: 573-586.

Soetaert, K., C. Heip and M. Vincx. - 1991. The meiobenthos along a Mediterranean deep-sea transect off Calvi (Corsica) and in adjacent canyon. P.S.Z.N.I: Mar. Ecol., 12: 227-242.

Soltwedel, T. - 2000. Metazoan meiobenthos along continental margins: a review. Prog. Oceanogr., 46: 59-84.

Theocharis, A., E. Balopoulos, S. Kioroglou, H. Kontoyiannis and A. Iona. - 1999. A synhtesis of the circulation and hydrography of the south Aegean Sea and the straits of the Cretan Arc (March 1994-January 1995). Prog. Oceanogr., 44: 469-509.

Thiel, H. - 1975. The size structure of deep-sea benthos. Int. Revue Ges. Hydrobiol., 60: 575-606.

Thiel, H. - 1983. Meiobenthos and nanobenthos of the deep-sea. In: G. Rowe (ed.), Deep-Sea Biol., pp. 167-230. Wiley, New York.

Tselepides, A. and N. Lampadariou. - 2004. Deep-sea meiofaunal community structure in the Eastern Mediterranean: are trenches benthic hotspots? Deep-Sea Res. I, 51: 833-847.

Tselepides, A., N. Lampadariou and E. Hatziyanni. - 2004. Distribution of meiobenthos at bathyal depths in the Mediterranean Sea. A comparison between sites of contrasting productivity. Sci. Mar., 68(Suppl. 3): 39-51.

Tselepides, A., T. Polychronaki, D. Marrale, I. Akoumianaki, A. Dell' Anno, A. Pusceddu and R. Danovaro. - 2000. Organic matter composition of the continental shelf and bathyal sediments of the Cretan Sea. Prog. Oceanogr., 46: 311-344.

Tyler, P.A. - 1988. Seasonality in the deep-sea. Oceanogr. Mar. Biol. Annu. Rev., 26: 227-258.

Vincx, M., B.J. Bett, A. Dinet, T. Ferrero, A.J. Gooday, P.J.D. Lambshead, O. Pfannkuche, T. Soltwedel and A. Vanreusel. - 1994. Meiobenthos of the Deep Northeast Atlantic. Adv. Mar. Biol., 30: 1-88.

Wassmann, P., J.E. Ypma and A. Tselepides. - 2000. Vertical flux of faecal pellets and microplankton on the shelf of the oligotrophic Cretan Sea (NE Mediterranean Sea). Prog. Oceanogr., 46: 241-258.

Weikert, H., R. Koppelmann and S. Wiegratz. - 2001. Evidence of episodic changes in deep-sea mesozooplankton abundance and composition in the Levantine Sea (Eastern Mediterranean). $J$. Mar. Syst., 30: 221-239.

Scient. ed.: J.B. Company.

Received January 24, 2008. Accepted October 8, 2008.

Published online March 4, 2009. 